\title{
Reflections on methods for assessing campus sustainability from a Lithuanian perspective
}

\author{
Authors: Diana Cibulskiene, Alina Gogitidze, Vladimir Kuvshinov, Laura Malyševa, \\ Kornelija Raišytè, Sofya Sharipko, Joost Platje
}

\section{Abstract}

Aim: Provide a summary of the discussion of focus group 1 at the workshop on "Methodology for assessing the campus sustainability from the perspective of multi-level antifragility" held in June 2016 at Siauliai University (Lithuania), as well as reflection notes each of the participant wrote after the workshop. The paper shows the outcome of the process of interaction and reflections of the authors.

Design / Research methods: This article contains feedback based on the experience and ideas from third year students of sustainable business from the University of Siauliai (Lithuania). Discussion took place during the workshop in focus groups. Afterwards, a discussion took place among all participating students and lecturers. After the workshop, the authors wrote individual feedback notes. These are summarized in this paper.

Conclusions / findings: Students may provide limited information on university viability and sustainability of the university's external environment due to lack of information on many indicators. Many indicators on which no information was available were considered to be irrelevant, being an example of the principle "what we do not see, does not count."

Originality / value of the article: The article provides critical feedback on an innovative approach towards research on campus sustainability.

Keywords: campus sustainability, sustainability management, fragility, antiHistory: received 2016-11-25, fragility, methodology corrected JEL: Q01, B40, 123 2016-11-27 


\section{Introduction}

This article provides a summary of the interaction of focus group 1 at the workshop on "Methodology for assessing the campus sustainability from the perspective of multi-level antifragility" held in June 2016 at Siauliai University (Lithuania). The reflections were drawn from discussions at the workshop, as well as reflection notes written after the workshop. First, some methodological issues are raised. Then, reflections on indicators are presented. An outline of the workshop as well as the indicators can be found in the first article of this special issue.

\section{Methodological issues}

An interesting element of the approach used in the workshop was that the discussion in the focus group was open. It was not directed in any way by the organizers. Because of this, the discussion was directed towards what the group members thought was relevant. Also, the open discussion led to a change in opinions of some participants. However, afterwards in the reflection notes it was mentioned that such a change in opinion may not necessarily be the result of proper argumentation. Such changes may also be based, for example, on a convincing story from a participant with strong discussion skills and/or authority.

This issue is relevant in the context of the limited information and knowledge people possess. As one participant noted: "Most likely, if I were to write the same essay, next week or a year from now, my views would not coincide, since new arguments would arise, a new day may bring a new perspective and so on." It was also noticed that indicators are often interrelated. Thus, a change in one indicator can lead to a kind of chain reaction, negatively influencing other indicators, which could seriously damage organizational viability. It seems that in an intuitive way the participants recognized the relevance of a system approach, where relations between indicators need to be researched.

\section{Indicators of campus viability and sustainability - some reflections}

Indicators such as "lack of knowledge", "low quality of teaching staff", "lack of critical discussion" as well as "students not questioning teachers during class" were considered to be relevant and interrelated. A teacher with poor knowledge is also unable to transfer knowledge to students. When graduates lack knowledge, this may harm the image (reputation) of the university, which may lead to lower student numbers and the university being less attractive as a place to work. Furthermore, graduates with poor knowledge may negatively influence the business or organization they will work for, while engaging in unsustainable activities. During the discussions, it was argued that the aim of the university to keep a good reputation makes the first part of the negative scenario unlikely. Employers will be less likely to employ graduates from universities they consider to be poor.

There was no clear agreement on the relation between students asking questions and a lack of knowledge. On the one hand, the argument was brought up that students are often rather interested in passing and obtaining a diploma than in acquiring knowledge. On the other hand, students who are inactive during class, may finish their studies and become successful. One reason may be that during their employment graduates obtain specific knowledge required for the job, while the university rather focuses on more general knowledge. It was mentioned that teachers are not really asked questions, or criticized, 
because they can get angry, which can have a negative impact on the mark. It was argued that this hampers the development of skills to identify problems and fragilities.

This aspect also appeared in the discussion on knowledge regarding sustainable development. This seems to be of particular importance in the context of the participants of the focus group being sixth semester students of a bachelor in Sustainable Business. One participant argued that some students finishing the programme may have little knowledge on sustainability issues. This brings forward the question whether such knowledge is really demanded by companies, a topic for deeper research. However, it was mentioned that when there is a need, a graduate may quickly catch up knowledge by way of self-study.

As a relevant indicator for the viability of the university, knowledge of foreign languages was identified. The reason is the need to attract foreign students, which is in particular important for small universities and universities with declining student numbers, like the Siauliai University. Foreign students help to prevent closure of some study programmed. The importance of this issue is based on own experience of the participants - all of them studies abroad for a while. It can be inferred from the discussion that in case of language problems, this issue increases in importance together with the increase in the number of foreign students.

The mentioned information and communication problems are related to the problem of lying and cheating as well as hiding the truth and a high level of secrecy. It was noticed that the indicators are probably correlated with corruption, and are expected to rather have an impact on organizational viability than on the sustainability of the external environment. Of course, the impact depends on the type of information which is kept behind or lied about. For example, lack of feedback on a student's mistake or wrong information provided by lecturers on the course requirement and expectations towards the students are likely to hamper learning-by-doing and the acquisition of knowledge. In this case, lying and cheating are related to low quality of teaching, discussed earlier. One issue requiring deeper research is whether and up to what moment lying and cheating is harmless. Another issue is whether what is considered to be a lie or cheating is illegal or not, and whether it is irrelevant. Also, when a disaster may happen, like an asteroid eventually destroying the Earth, and such a potential apocalypse is announced every half year, this may lead to chaos or disbelief in any information on such events. At such a moment, a question appears whether it is better to deny such information. The situation seems to be more clear in the case of withholding information or lying about the financial situation of a university (e.g., debt), as this can be very harmful.

Regarding environmental issues, lying and cheating was related to corruption. In a corrupt environment, with a lack of or failure of legislation, where no information about environmental problems becomes public, this can have serious negative impact on the environment through environmentally-harming investments. Several times during the discussion it was mentioned that corruption is in fact a kind of cheating.

The existence of closed networks of family and friends as well as the employment of them were considered to be irrelevant. One reason was that such a situation was not experienced by the participants. A reason why such a situation is irrelevant is that teaching staff at least should have some minimum skills, in order not to harm the reputation of the university. Dependence on a few scientists or IT was also 
not really considered to be relevant. This because of the profile of the university. This shows that many participants assessed the importance of general indicators based on their own experience.

\section{Concluding remarks}

While some important issues were raised in this paper, awareness exists that students do not have access to all types of information needed to assess the indicators of campus sustainability. This poses a limit to the general applicability of the issues identified. Many indicators not discussed were considered to be irrelevant. One reason was a lack of information on them.
Other university stakeholders may shed a different light on them. One main element appeared in the discussion. New students are relevant for university viability. The declining number of students at Siauliai University had probably an important impact on the direction of the discussion as well as the interpretation of the importance of indicators as well as their interrelation. This is also probably the bottom-line of university viability - without students a university cannot exist. As a consequence, it is quite likely that in case of declining student numbers, when not forced by, e.g., student and labour market demands, sustainability is unlikely to receive much attention. This is an issue requiring deeper research.

\title{
Uwagi o metodach oceny zrównoważonego rozwoju kampusu z perspektywy litewskiej
}

\begin{abstract}
Abstrakt
Cel: Tekst zawiera streszczenie dyskusji prowadzonych w grupie fokusowej $\mathrm{nr} 1$ podczas warsztatów na temat „Metodologia oceny zrównoważonego rozwoju kampusu z perspektywy antykruchości wielopoziomowej" zorganizowanej przez Uniwersytet Szawelski na Litwie w lipcu 2016 r. oraz uwagi wynikające z notatek pozostawionych przez każdego uczestnika po warsztatach. Artykuł pokazuje wynik procesu integracji i refleksji autorów.

Metoda badawcza: Artykuł zawiera informacje zwrotną opartą na doświadczeniu i poglądach studentów trzeciego roku zrównoważonego biznesu z Uniwersytetu Szawelskiego na Litwie. Dyskusja miała miejsce podczas warsztatów i przebiegała w grupach fokusowych, a następnie z udziałem wszystkich uczestników i wykładowców. Po warsztatach uczestnicy byli proszeni o sporządzenie notatek z informacją zwrotną. Notatki te są streszczone w artykule. Wnioski: Studenci mogą mieć niewystarczające informacje o żywotności i zrównoważonym rozwoju uniwersytetu z powodu braku informacji o wielu wskaźnikach. Takie wskaźniki często uważano za wskaźniki nierelewantne, zgodnie z zasadą „czego nie widać, to się nie liczy”.

Oryginalność / wartość artykułu, wkład w rozwoju nauki: Artykuł dostarcza krytycznej informacji zwrotnej na temat innowacyjnego podejścia w badaniach nad zrównoważonego rozwoju kampusu.
\end{abstract}

Słowa kluczowe: zrównoważony rozwój kampusu, zarządzanie zrównoważonego rozwoju, kruchość, antykruchość, metodologia 